\title{
GASES OBTAINED FROM COMMERCIAL FELDSPARS HEATED IN VACUO
}

\author{
By G. R. Shelton and H. H. Holscher ${ }^{1}$
}

\section{ABSTRACT}

This paper constitutes a preliminary report of an investigation to determine quantitatively the gases obtained by heating a feldspar in vacuo. Nineteen samples representative of the ground commercial material, such as is used in the ceramic industry, were tested. At $1,000^{\circ} \mathrm{C}$. the gases consisted, by weight, of 32 to 96 per cent water vapor, 0 to 59 per cent acid gases, and 0 to 36 per cent unabsorbed gases. Calculated to volume relations a unit of feldspar when heated to $1,000^{\circ} \mathrm{C}$. would evolve (extremes for the 19 samples) 16 to 140 volumes of water vapor and 0 to 15 volumes of acid gases (assumed to be $\mathrm{CO}_{2}$ ) measured at $1,000^{\circ} \mathrm{C}$.

\section{CONTENTS}

I. Introduction. 347

II. Materials 348

III. Method 348

IV. Apparatus

V. Procedure 348

VI. Experimental data 349

1. Results at $1,000^{\circ} \mathrm{C}$

2. Loss on ignition as basis for calculating kaolinite. 351

3. Effects of temperature.

4. Flint and mica

5. Minor gas constituents

6. Volume relations of gases

VII. Summary and conclusions 351

352

353

355

355

355

356

VIII. Acknowledgments

356

\section{INTRODUCTION}

This paper constitutes a preliminary report on an investigation which has for its purpose the determination of the nature and quantity of gases obtained from a number of typical ground commercial feldspar when heated in a vacuum.

There is a possibility that gases derived from such feldspars or the minerals normally associated with commercial feldspars during the firing process may affect some of the physical properties of bodies and glazes in which feldspar is one of the principal ingredients; for example, the minute gas bubbles in dental porcelain of high feldspar content might be expected to originate from the gas evolved from the feldspar or associated minerals.

Various investigators have analyzed the gases obtained from lavas and rocks when heated in vacuo. Shepherd ${ }^{2}$ found water vapor to be the most important constituent of gases yielded by these materials. Chamberlain ${ }^{3}$ lists over 100 analyses of gases extracted from rocks and minerals and gives a complete review of the subject up to the time of his publication.

1 Cooperative fellow, Bureau of Standards and Engineering Experiment Station of Ohio State University. 2 E. S. Shepherd, The Analysis of Gases Obtained from Volcanoes and from Rocks, J. Geol., rol. 33, p. 289, 1925. E. S. Shepherd and H. E. Merwin, J. Geol., vol. 35, p. 97, 1927.

8 R. T. Chamberlain, Gases in Rocks, Carnegie Institu te of Washington, Publication No. 106, 1908. 


\section{MATERIALS}

The 19 feldspar samples investigated were portions of the same ground commercial samples previously studied at the Bureau of Standards, on which fairly comprehensive data have been published. ${ }^{4}$ It must be noted that the feldspars are not pure minerals, but that they contain other minerals, such as quartz, hornblende, biotite, muscovite, and calcite in varying quantities as indicated by Insley.

\section{METHOD}

A discussion of gravimetric methods for the determination of gases at low pressures is given by Jordan, Swindells, and Eckman. ${ }^{5}$ As a result of their work on the efficiency of gas absorbents at rather low pressures solid reagents were found to be most suitable. Consequently, in the present investigation phosphours pentoxide was used for the absorption of water vapor and ascarite for acid gases. Provision was made for the oxidation of hydrogen and carbon monoxide by passing the gases over heated copper oxide. The water vapor and carbon dioxide formed were then absorbed by phosphorus pentoxide and ascarite, respectively.

\section{APPARATUS}

The apparatus used in this investigation was developed at the Bureau of Standards for the analysis of gases obtained from metals by fusion in vacuo. 6 Its essential parts consisted of a method for circulating and absorbing the gases, which is completely described by Vacher and Jordan, and of a furnace for heating the specimen in vacuo.

The furnace was of the usual platinum-resistance type, having an auxiliary heater. ${ }^{7}$ The vacuum chamber (fig. 1) consisted of a fused silica tube, 1 inch inside diameter and 12 inches long, closed at the bottom. The open end of this tube, projecting from the furnace, was fitted with a water-jacketed brass tube, the joint between the two tubes being sealed with picein cement. The brass tube was joined to the glass system of the apparatus, picein cement being used to seal this joint also. Additional cooling of the end of the tube projecting from the furnace was obtained by means of a cooling coil attached to the container with zinc cement. This cement was made by moistening with sodium silicate solution a 1 to 1 mixture of powdered and granular (20 to $30 \mathrm{mesh}$ ) metallic zinc. The mixture was dried first at room temperature and finally at about $150^{\circ} \mathrm{C}$.

Furnace temperatures were determined by means of a platinum to platinum-rhodium thermocouple, permanently mounted inside the furnace, so that it touched the outside of the vacuum chamber. Fre quent comparisons of this couple with a standard couple were made.

1 H. Insley, J. Am. Cer. Soc., vol. 10 (9), p. 651, 1927. R. F. Geller and A. S. Creamer, J Am. Cir. Soc., vol., 14 (1), p. 30,1931 .

8 L. Jordan and F. E. Swindells, Cases in Metals: I. BS. Sci. Paper No. 457, 1922 . L. Gordan and J. R. Eckman, Gases in Metals, II. B. S. Sci. Paper No. 514, 1925; III. B. S. Sci. Paper No. 563, 1927.

6 H. C. Vacher and Louis Jordan, The Determination of Oxygen and Nitrogen in Irons and Steels by the Vacuum-Fusion Method, B. S. Jour. Research, vol. 7 (2), p. 375, August, 1931.

725 feet of 25 -gage platinum wire were wound, 12 turns to the inch, on the inner refractory tube 2 inches in diameter. Coaxial with this tube was one 4 inches in diameter wound with nichrome ribbon, which constituted the auxiliary heater. The space between the tubes was filled with $\mathrm{Al}_{2} \mathrm{O}_{3}$, and the larger tube was insulated with diatomaceous earth. Asbestos boards at top and bottom of the metal cylinder held the tubes in place. 


\section{PROCEDURE}

Before each test was made on a feldspar sample, the vacuum chamber was heated to $1,000^{\circ} \mathrm{C}$. and allowed to cool to room temperature, with the pressure in the entire system reduced to $1 \mathrm{~mm}$ or less.

Approximately $10 \mathrm{~g}^{8}$ of feldspar, previously dried at $105^{\circ}$ to $110^{\circ} \mathrm{C}$., were placed in a weighed fused silica test tube and then put into the vacuum chamber, which in turn was lowered into the furnace. The brass tube was sealed to the container and the glass welded to the analytical train as already explained. The ascarite and phosphorus pentoxide tubes were filled, ${ }^{9}$ connected to the apparatus and evacuated to about $2 \mathrm{~mm}$ pressure. The evacuated tubes were then removed and weighed, the lubricant having been removed from the tips of the side arms with ether. Trials indicated that constant weight of the tubes was obtained after repeated lubricating and cleaning of the side arms. The weighed evacuated tubes were again connected to the apparatus, and the glass system evacuated to $2 \mathrm{~mm}$ or less. Before proceeding further, tests were made for leaks. ${ }^{10}$ Pressure was read on the McLeod gauge, which was then shut off from the system and the ascarite tube was closed. The stopcocks were adjusted so that the gases were forced to circulate through the phosphorus pentoxide tube. The furnace was then heated

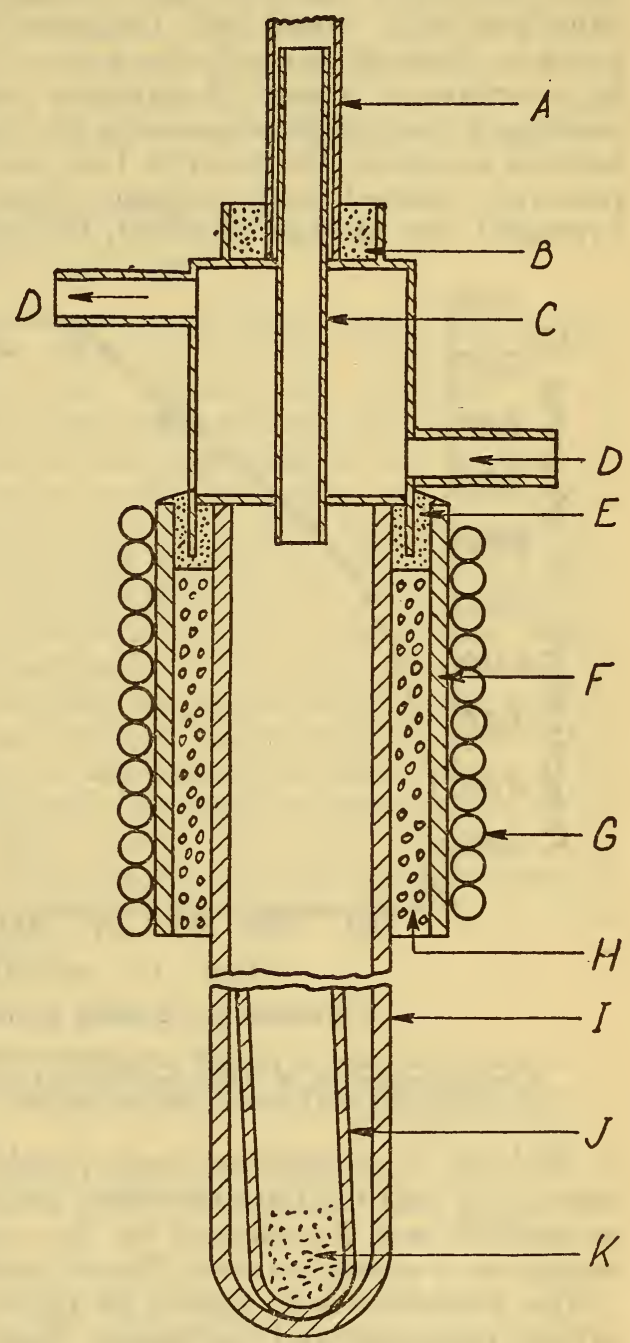

Figure 1.-Sample container

$A$, pyrex tubing leading to glass system; $B$, picein cement $C$, water-jacketed brass tube; $D$, water inlet and outlet; $E$, picein cement; $F$, brass collar with soldered coil $G ; H$, zinc cement; $I$, fused silica vacuum chamber; $J$, fused silica test tube with feldspar sample $\mathrm{K}$.

8 Preliminary tests indicated that sufficient gas could be obtained from a $10 \mathrm{~g}$ sample of feldspar to give checks within the limits of error of the method employed.

- Ascarite will lose water slowly if kept for a long time in an evacuated system. Although not done in this study, it is advisable to pack small amounts of $\mathrm{P}_{2} \mathrm{O}_{5}$ on each side of the ascarite.

$10 \mathrm{~A}$ high-frequency violet ray machine was used in testing for leaks. The terminals were held on opposite sides of the tube or stopcock being tested. The path of the spark between the terminals always passed through the leak, making its location a simple matter. 
to $1,000^{\circ} \mathrm{C}$. according to the heating schedule shown in Figure 2. This temperature was held constant for 30 minutes, and the heating current turned off. During this period and for 30 minutes after the heating current was turned off, the gases from the feldspar were circulated through the phosphorus pentoxide tube. ${ }^{11}$ The tube was then closed and the ascarite tube opened, causing the gases to circulate through the latter. Pressure readings were made at intervals of about 15 minutes, lower pressures indicating the continued absorption of gases in the tube. After the pressure had become constant, the ascarite tube was also closed, and both tubes removed, cleaned, and weighed. The furnace was allowed to cool overnight, dry air was admitted, the test tube containing the sample

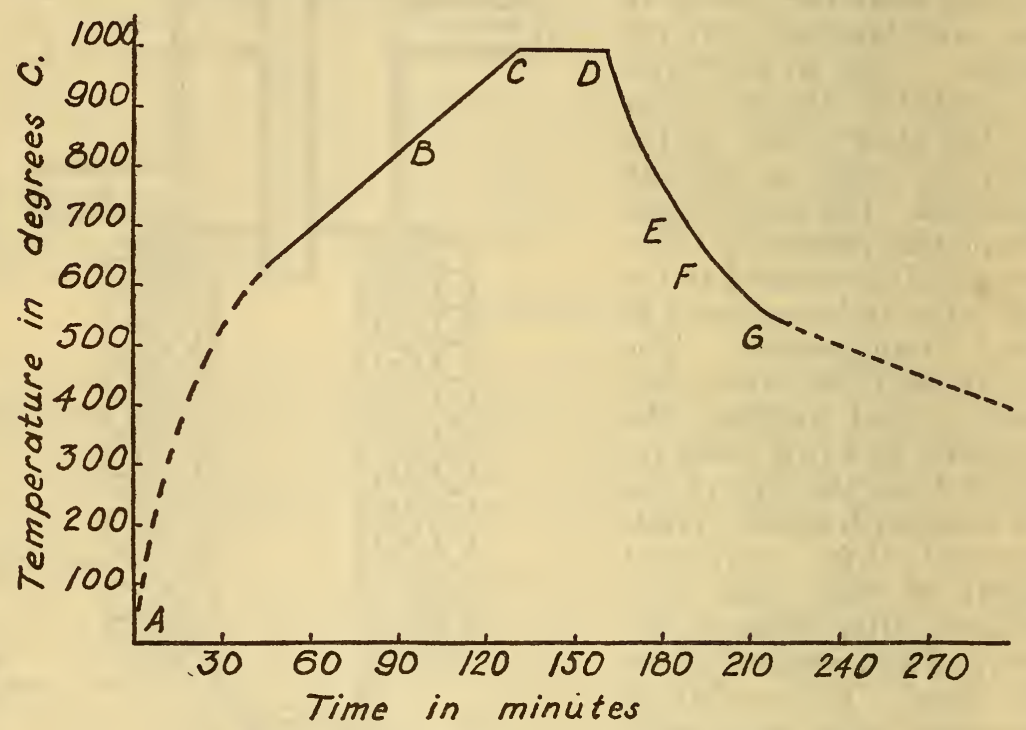

Figure 2.-Heating schedule of feldspars

$A$, ascarite tube closed; $B$, rheostat setting raised; $C$, temperature $1,000^{\circ}$ held for 30 minutes; $D$, heating current off; $E, \mathrm{P}_{2} \mathrm{O}_{3}$ tube closed and ascarite tube opened; $F$, pressure read; $G$, pressure constant, and tubes removed and weighed.

of feldspar was removed and reweighed. Blank determinations were made and the data corrected accordingly. Total loss of weight on ignition was determined by the usual method of heating a $1 \mathrm{~g}$ sample in a crucible over a Fisher burner.

The procedure was altered as follows when tests were made for carbon monoxide and hydrogen: Water and acid gases were determined as explained above. The absorption tubes were again connected to the system, the adjoining part of which was then evacuated. The gases in the remainder of the system were passed through a $U$ tube filled with copper oxide heated to $300^{\circ} \mathrm{C}$. in order to oxidize hydrogen to water and carbon monoxide to carbon dioxide. Any water vapor formed would be absorbed in the $\mathrm{P}_{2} \mathrm{O}_{5}$ tube and carbon dioxide by the

11 Tests indicated that this procedure was necessary to avoid condensation of water in the glass system connected with the furnace. If water were permitted to condense, a much longer time was required for its absorption by the $\mathrm{P}_{2} \mathrm{O}_{3}$. 
ascarite. The circulation of gases was continued until pressure readings became constant. From the weighed amounts of $\mathrm{CO}_{2}$ and $\mathrm{H}_{2} \mathrm{O}$ thus obtained, the quantities of $\mathrm{CO}$ and $\mathrm{H}_{2}$ originally present in the gases could be calculated. A correction was made for the gas inevitably lost when the absorption tubes were disconnected from the system and weighed, before oxidation of $\mathrm{CO}$ and $\mathrm{H}_{2}$ was begun. Knowing the volume of the entire system and also the volume of the system adjoining the absorption tubes (between stopcocks 2, 3, and 5) it was possible to calculate the gas lost and its percentage of $\mathrm{CO}$ and $\mathrm{H}_{2}$.

\section{EXPERIMENTAL DATA}

\section{RESULTS AT $1,000^{\circ} \mathrm{C}$.}

The results obtained from the various feldspars, using the heating schedule shown in Figure 2, are given in Table 1. Duplicate determinations, reported in many cases, indicate the precision to be expected. The anyalytical data have" been corrected according to the blank determinations given at the beginning of the table. Inspection of this table indicates that good agreement was, in general, obtained between the analytical data and total loss on ignition. This indicates that the amount of gases evolved by feldspars at $1,000^{\circ}$ C. in a vacuum is no greater than ignition loss, the slight difference probably being due to unavoidable errors. In every case except one (feldspar No. 12, first determination) the total gain in weight of the two absorption tubes is less than the loss in weight of the sample heated in the furnace. This may indicate the presence of gases other than these absorbed, or it may be due to experimental errors. The amount of the gaseous constituents, expressed as percentage of the total gas, varied as follows: Water vapor 32 to 96 , acid gases 0 to 59 , and other gases 0 to 36 . Water vapor constituted more than 50 per cent of the absorbed gases obtained from every feldspar studied with the exception of Nos. 2 and 5.

TABLE 1.-Gases evolved by 19 typical ground feldspars

[Results of determinations at $1,000^{\circ} \mathrm{C}$.]

\begin{tabular}{|c|c|c|c|c|c|c|c|c|c|}
\hline \multirow{2}{*}{ Feldspar No.1 } & \multicolumn{2}{|c|}{ Gain in weight } & \multirow{2}{*}{$\begin{array}{c}\text { Total } \\
\text { gain in } \\
\text { weight }\end{array}$} & \multirow{2}{*}{$\begin{array}{l}\text { Loss of } \\
\text { sample }\end{array}$} & \multirow{2}{*}{$\begin{array}{l}\text { Differ- } \\
\text { ence }^{2}\end{array}$} & \multirow{2}{*}{$\begin{array}{c}\text { Loss on } \\
\text { igni- } \\
\text { tion }\end{array}$} & \multicolumn{3}{|c|}{$\begin{array}{l}\text { Composition by weight } \\
\text { of evolved gases }\end{array}$} \\
\hline & $\begin{array}{c}\text { Ascarite } \\
\text { tube }\end{array}$ & $\begin{array}{l}\mathrm{P}_{2} \mathrm{O}_{8} \\
\text { tube }\end{array}$ & & & & & $\begin{array}{l}\text { Acid } \\
\text { gases }\end{array}$ & Water & $\begin{array}{l}\text { Other } \\
\text { gases }\end{array}$ \\
\hline \multirow{5}{*}{ Average.... } & $\left\{\begin{array}{c}\text { Per cent } \\
0.002 \\
.00 \\
.02\end{array}\right.$ & $\begin{array}{c}\text { Per cent } \\
0.016 \\
.19 \\
.21 \\
\end{array}$ & $\begin{array}{c}\text { Per cent } \\
0.018 \\
.19 \\
.23\end{array}$ & $\begin{array}{c}\text { Per cent } \\
0.026 \\
.23 \\
.24\end{array}$ & $\begin{array}{c}\text { Per cent } \\
0.008 \\
.04 \\
.01\end{array}$ & $\begin{array}{r}\text { Per cent } \\
0.27 \\
.27\end{array}$ & Per cent & Per cent & Per cent \\
\hline & .01 & .20 & .21 & .24 & .03 & .27 & 4 & 84 & 12 \\
\hline & .20 & .11 & .31 & .34 & .03 & .40 & 59 & 32 & 9 \\
\hline & $\left\{\begin{array}{l}.11 \\
.10 \\
.09\end{array}\right.$ & $\begin{array}{l}.28 \\
.37 \\
.32\end{array}$ & $\begin{array}{l}.39 \\
.47 \\
.41\end{array}$ & $\begin{array}{l}.50 \\
.56 \\
.48\end{array}$ & $\begin{array}{l}.11 \\
.09 \\
.07\end{array}$ & $\begin{array}{l}.50 \\
.53 \\
.48\end{array}$ & - & $--\cdot$. & - \\
\hline & .10 & .32 & .42 & .51 & .09 & .50 & 20 & 62 & 18 \\
\hline
\end{tabular}

1 The sample numbers used are the same as those used by Geller and Creamer, Investigation of Feldspar and Its Effect in Pottery Bodies, J. Am. Cer. Soc., vol. 14, No. 1, January, 1931.

2 Includes nonabsorbed gases and any material which may volatilize in the crucible, but condense before reaching the analytical train. 
TABLE 1.-Gases evolved by 19. typical ground feldspars-Continued

[Results of determinations at $1,000^{\circ} \mathrm{C}$.]

\begin{tabular}{|c|c|c|c|c|c|c|c|c|c|}
\hline \multirow{2}{*}{ Feldspar No. } & \multicolumn{2}{|c|}{ Gain in weight } & \multirow{2}{*}{$\begin{array}{l}\text { Total } \\
\text { gain in } \\
\text { weight }\end{array}$} & \multirow{2}{*}{$\begin{array}{l}\text { Loss of } \\
\text { sample }\end{array}$} & \multirow{2}{*}{$\begin{array}{l}\text { Differ- } \\
\text { ence }\end{array}$} & \multirow{2}{*}{$\begin{array}{c}\text { Loss on } \\
\text { igni- } \\
\text { tion }\end{array}$} & \multicolumn{3}{|c|}{$\begin{array}{l}\text { Composition by weight } \\
\text { of evolved gases }\end{array}$} \\
\hline & $\begin{array}{c}\text { Ascarite } \\
\text { tube }\end{array}$ & $\begin{array}{l}\mathrm{P}_{2} \mathrm{O}_{3} \\
\text { tube }\end{array}$ & & & & & $\begin{array}{l}\text { Acid } \\
\text { gases }\end{array}$ & Water & $\begin{array}{l}\text { Other } \\
\text { gases }\end{array}$ \\
\hline \multirow{3}{*}{ Average.. } & $\left\{\begin{array}{c}\text { Per cent } \\
0.21 \\
.20\end{array}\right.$ & $\begin{array}{c}\text { Per cen } \\
0.39 \\
.45\end{array}$ & $\begin{array}{c}\text { Per cent } \\
0.60 \\
.65\end{array}$ & $\begin{array}{c}\text { Per cent } \\
0.71 \\
.70\end{array}$ & $\begin{array}{c}\text { Per cent } \\
0.11 \\
.05\end{array}$ & Per cent & \begin{tabular}{l} 
Per cent \\
\hdashline
\end{tabular} & Per cent & Per cent \\
\hline & .20 & .42 & .62 & .70 & .08 & -...... & 29 & 60 & 11 \\
\hline & $\left\{\begin{array}{l}.25 \\
.22\end{array}\right.$ & $\begin{array}{l}.20 \\
.19\end{array}$ & $\begin{array}{l}.45 \\
.41\end{array}$ & $\begin{array}{l}.46 \\
.50\end{array}$ & $\begin{array}{l}.01 \\
.09\end{array}$ & $\begin{array}{l}.50 \\
.57\end{array}$ & & -... & 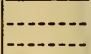 \\
\hline \multirow[t]{2}{*}{ Average_. } & .24 & .20 & .43 & .48 & .05 & .54 & 49 & 41 & 10 \\
\hline & $\left\{\begin{array}{l}.04 \\
.03 \\
.02\end{array}\right.$ & $\begin{array}{l}.31 \\
.33 \\
.35\end{array}$ & $\begin{array}{l}.35 \\
.36 \\
.37\end{array}$ & $\begin{array}{l}.42 \\
.48 \\
.45\end{array}$ & $\begin{array}{l}.07 \\
.12 \\
.08\end{array}$ & $\begin{array}{l}.48 \\
.51 \\
.46\end{array}$ & & & $\cdots$ \\
\hline \multirow[t]{2}{*}{ A verage... } & .03 & .33 & .36 & .45 & .09 & .48 & 7 & 73 & 20 \\
\hline & $\left\{\begin{array}{l}.04 \\
.02\end{array}\right.$ & $\begin{array}{l}.34 \\
.40\end{array}$ & $\begin{array}{l}.38 \\
.42\end{array}$ & $\begin{array}{l}.46 \\
.47\end{array}$ & .08 & $\begin{array}{l}.46 \\
.47\end{array}$ & & & \\
\hline \multirow[t]{2}{*}{ Average... } & .03 & .37 & .40 & .47 & .07 & .47 & 6 & 79 & 15 \\
\hline & $\begin{array}{l}.18 \\
.19 \\
.18 \\
.18\end{array}$ & $\begin{array}{l}.23 \\
.25 \\
.29 \\
.28\end{array}$ & $\begin{array}{l}.41 \\
.44 \\
.47 \\
.46\end{array}$ & $\begin{array}{l}.70 \\
.71 \\
.72\end{array}$ & $\begin{array}{l}.26 \\
.24 \\
.26\end{array}$ & $\begin{array}{l}.64 \\
.69 \\
.65 \\
.65\end{array}$ & $\mid$\begin{tabular}{c}
-1 \\
\hdashline-1
\end{tabular} & 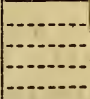 & - \\
\hline \multirow[t]{2}{*}{ Average... } & .18 & .26 & .44 & .71 & .25 & .66 & 26 & 38 & 36 \\
\hline & $\left\{\begin{array}{l}.03 \\
.07 \\
.06 \\
.03 \\
.01\end{array}\right.$ & $\begin{array}{l}.19 \\
.33 \\
.18 \\
.12 \\
.14\end{array}$ & $\begin{array}{l}.22 \\
.40 \\
.24 \\
.15 \\
.15\end{array}$ & $\begin{array}{l}.26 \\
.42 \\
.24 \\
.13 \\
.17\end{array}$ & $\begin{array}{r}.04 \\
.02 \\
.00 \\
-0.02 \\
.02\end{array}$ & $\begin{array}{l}.33 \\
.47 \\
.25 \\
.17 \\
.20\end{array}$ & $\begin{array}{r}12 \\
16 \\
25 \\
-1 \\
-.-\end{array}$ & $\begin{array}{r}73 \\
79 \\
75 \\
-\cdots \\
-.-\end{array}$ & $\begin{array}{r}15 \\
5 \\
0 \\
0 \\
\end{array}$ \\
\hline \multirow[t]{2}{*}{ Average.. } & .02 & .13 & .15 & .15 & .00 & .19 & 13 & 87 & 0 \\
\hline & $\left\{\begin{array}{l}.02 \\
.01 \\
.01\end{array}\right.$ & $\begin{array}{l}.20 \\
.22 \\
.20\end{array}$ & $\begin{array}{l}.22 \\
.23 \\
.21\end{array}$ & $\begin{array}{l}.29 \\
.28 \\
.26\end{array}$ & $\begin{array}{l}.07 \\
.05 \\
.05\end{array}$ & $\begin{array}{l}.30 \\
.30 \\
.26\end{array}$ & & & \\
\hline \multirow[t]{3}{*}{ A verage } & .01 & .21 & .22 & .28 & .06 & .29 & 4 & 75 & 21 \\
\hline & $\begin{array}{l}.01 \\
.02 \\
.00 \\
.00\end{array}$ & $\begin{array}{r}.26 \\
.19 \\
.24 \\
.94\end{array}$ & $\begin{array}{l}.27 \\
.21 \\
.24 \\
.94\end{array}$ & $\begin{array}{l}.30 \\
.23 \\
.27 \\
.98\end{array}$ & $\begin{array}{l}.03 \\
.02 \\
.03 \\
.04\end{array}$ & $\begin{array}{l}.28 \\
.24 \\
.31 \\
.95\end{array}$ & $\begin{array}{l}3 \\
9 \\
0 \\
0\end{array}$ & $\begin{array}{l}87 \\
82 \\
89 \\
96\end{array}$ & $\begin{array}{r}10 \\
9 \\
11 \\
4\end{array}$ \\
\hline & $\begin{array}{l}.02 \\
.08 \\
.01\end{array}$ & $\begin{array}{r}1.02 \\
.15 \\
.18\end{array}$ & $\begin{array}{r}1.04 \\
.23 \\
.19\end{array}$ & $\begin{array}{l}.26 \\
.21\end{array}$ & $\begin{array}{l}.03 \\
.02\end{array}$ & $\begin{array}{r}1.03 \\
.29 \\
.21\end{array}$ & $\begin{array}{r}3 \overline{1} \\
5\end{array}$ & 85 & $\begin{array}{l}11 \\
10\end{array}$ \\
\hline
\end{tabular}

The presence of such minerals as muscovite, pyrite, and calcite in the commercial feldspars ${ }^{12}$ may account for some of the variations noted in the analyses of gases obtained from them. For instance the high percentage of acid gases in feldspar No. 5 was undoubtedly due in part to carbon dioxide derived from calcite found in this sample by microscopic examination.

\section{LOSS ON IGNITION BASIS FOR CALCULATING KAOLINITE}

Since the gas obtained by heating a feldspar is a mixture and not pure water vapor, the loss on ignition of a feldspar should not be used in calculating its kaolinite content, except where approximate results 
only are desired. Otherwise too high a percentage of kaolinite would be indicated.

\section{EFFECTS OF TEMPERATURE}

A study was made of the amounts of water vapor and acid gases obtained from feldspars when the temperature to which they are heated is gradually increased. A preliminary investigation was made to determine the loss on ignition of four feldspars, Nos. 1, 4, 15, and 19. Gram samples were heated at $105^{\circ}, 200^{\circ}, 300^{\circ}, 400^{\circ}, 500^{\circ}, 600^{\circ}$, and $750^{\circ} \mathrm{C}$. in a Hoskins muffle furnace. The temperature was held constant for a period of three days when the sample was removed, cooled in a dessicator, and weighed. The furnace temperature having been increased by $100^{\circ} \mathrm{C}$., the sample was returned and allowed to

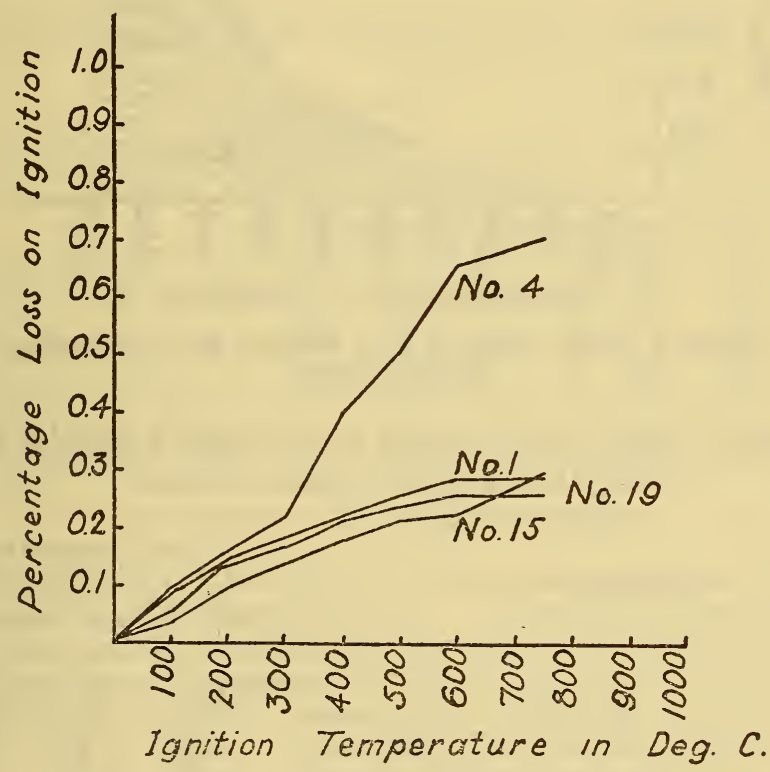

FIGURE[3.-Rate of loss on ignition of four feldspars at various temperatures

remain at the higher temperature for a second period of three days. The results are given in Table 2 and are also shown in the form of curves in Figure 3.

Feldspar No. 5 was selected for vacuum treatment at various temperatures, since in previous tests it was found to yield a large amount of acid gases. (See Table 1.) Following the procedure described in Section V, the sample was heated to $400^{\circ} \mathrm{C}$. and then the increase in weight of the absorption tubes and the decrease in weight of the sample in the vacuum furnace were determined. The sample was returned to the furnace and a similar determination made at $500^{\circ} \mathrm{C}$., the process being repeated at $100^{\circ}$ intervals up to $1,000^{\circ} \mathrm{C}$. The results are given in Table 3 and plotted as curves in Figure 4. Water vapor is the chief constituent of the gas obtained at $400^{\circ} \mathrm{C}$., the quantity reaching a maximum between $800^{\circ}$ and $900^{\circ} \mathrm{C}$. The evolution of acid gases starts between $400^{\circ}$ and $500^{\circ} \mathrm{C}$., becomes most rapid at 
about $700^{\circ}$ C., and is practically completed at $800^{\circ}$ C. Small amounts of gases other than water vapor and acid gases were indicated as low as $600^{\circ} \mathrm{C}$. Since all the weight of experimental errors falls on the determination of these unabsorbed gases, the values obtained for them should not be overemphasized.

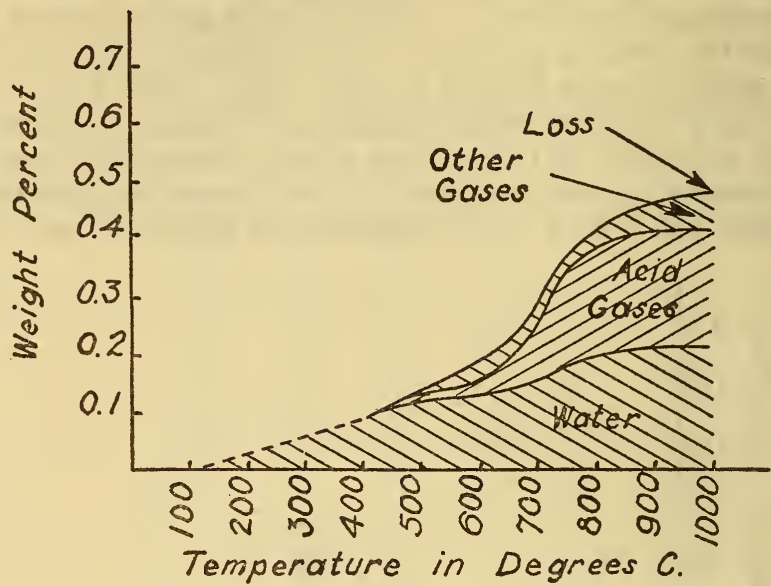

Figure 4.-Gases obtained from feldspar No. 5 at various temperatures

TABLE 2.-Rate of loss on ignition of four feldspars headed in air

(Time of heating: three days at each temperature)

\begin{tabular}{|c|c|c|c|c|}
\hline \multirow{2}{*}{ Temperature $\left({ }^{\circ} \mathrm{C}.\right)$} & \multicolumn{4}{|c|}{ Loss in weight of feldspar } \\
\hline & No. 1 & No. 4 & No. 15 & No. 19 \\
\hline $\begin{array}{l}105 \\
200\end{array}$ & $\begin{array}{r}\text { Per cent } \\
0.08 \\
.14 \\
.18 \\
.22 \\
.25 \\
.28 \\
.28\end{array}$ & $\begin{array}{r}\text { Per cent } \\
0.09 \\
.16 \\
.22 \\
.41 \\
.50 \\
.66 \\
.70\end{array}$ & $\begin{array}{r}\text { Per cent } \\
0.04 \\
.09 \\
.13 \\
.18 \\
.21 \\
.22 \\
.29\end{array}$ & $\begin{array}{r}\text { Per cent } \\
0.06 \\
.13 \\
.17 \\
.21 \\
.24 \\
.26 \\
.26\end{array}$ \\
\hline Loss between 105-750 .... & .20 & .61 & .25 & .20 \\
\hline Loss on ignition 1 & .27 & .64 & .24 & .21 \\
\hline
\end{tabular}

1 Of sample dried at $105-110^{\circ} \mathrm{C}$. Table 1.

TABLE 3.-Gases evolved from feldspar 5 at various temperatures

\begin{tabular}{|c|c|c|c|c|c|c|}
\hline Temperature $\left({ }^{\circ} \mathrm{C}.\right)$ & $\begin{array}{l}\text { Acid } \\
\text { gases }\end{array}$ & Water & Total & $\begin{array}{l}\text { Loss of } \\
\text { sample }\end{array}$ & $\begin{array}{c}\text { Differ- } \\
\text { ence }\end{array}$ & $\begin{array}{l}\text { Loss on } \\
\text { ignition }\end{array}$ \\
\hline $\begin{array}{l}400 \\
5000 \\
600 \\
800 \\
900 \\
1,000\end{array}$ & $\begin{array}{r}\text { Per cent } 1 \\
0.00 \\
.01 \\
.02 \\
.10 \\
.20 \\
.21 \\
.20\end{array}$ & \begin{tabular}{r|} 
Per cent 1 \\
0.09 \\
.12 \\
.12 \\
.16 \\
.19 \\
.21 \\
.21
\end{tabular} & $\begin{array}{r}\text { Per cent } 1 \\
0.09 \\
.13 \\
.14 \\
.26 \\
.39 \\
.42 \\
.41\end{array}$ & $\begin{array}{r}\text { Per cent } 1 \\
0.09 \\
.12 \\
.18 \\
.29 \\
.42 \\
.45 \\
.48\end{array}$ & $\begin{array}{r}\text { Per cent } 1 \\
0.00 \\
-.01 \\
.04 \\
.03 \\
.03 \\
.03 \\
.07\end{array}$ & $\begin{array}{c}\text { Per cent } \\
0 \\
0.50\end{array}$ \\
\hline
\end{tabular}

1 Accumulative per cent. 


\section{FLINT AND MICA}

Flint and mica being the two most common impurities in commercial feldspar used in the ceramic industries, a determination of the gas obtained from each was made by using the same procedure employed in case of the feldspars. The flint was a commercially ground quartz sand, and the mica was also a ground commercial product. The mica was of coarser grain than the feldspar.

The results of these tests are given in Table 4. Water was the only gas obtained from the flint, but both water and acid gases were evolved by the mica. In analyzing gases obtained from feldspars the results would not be seriously affected by the acid gases derived from the small amounts (less than 4 per cent) of mica present.

TABLE 4.-Results obtained when using copper oxide to determine $\mathrm{CO}$ and $\mathrm{H}_{2}$ at $1,000^{\circ} \mathrm{C}$.

\begin{tabular}{|c|c|c|c|c|c|c|c|c|}
\hline Sample No. & $\begin{array}{l}\text { Acid } \\
\text { gases }\end{array}$ & Water & $\mathrm{CO}$ & $\mathrm{H}_{2}$ & Total & $\begin{array}{l}\text { Loss of } \\
\text { sample }\end{array}$ & $\begin{array}{c}\text { Differ- } \\
\text { ence }\end{array}$ & $\begin{array}{l}\text { Loss on } \\
\text { ignition }\end{array}$ \\
\hline 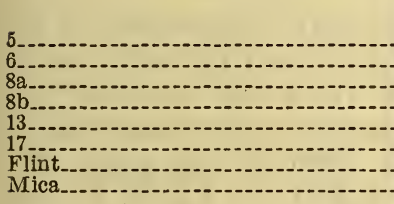 & $\begin{array}{c}\text { Per cent } \\
0.22 \\
.01 \\
.18 \\
.18 \\
.01 \\
.02 \\
.00 \\
.20\end{array}$ & $\begin{array}{r}\text { Per cent } \\
0.19 \\
.35 \\
.29 \\
.28 \\
.20 \\
1.02 \\
.09 \\
4.11\end{array}$ & $\begin{array}{c}\text { Per cent } \\
0.00 \\
.00 \\
.12 \\
.08 \\
.00 \\
.00 \\
.00 \\
.00\end{array}$ & $\begin{array}{r}\text { Per cent } \\
0 \\
0 \\
0 \\
0 \\
0 \\
0 \\
0 \\
0\end{array}$ & $\begin{array}{c}\text { Per cent } \\
0.41 \\
.36 \\
.59 \\
.54 \\
.21 \\
1.04 \\
.09 \\
4.31\end{array}$ & $\begin{array}{c}\text { Per cent } \\
0.50 \\
.45 \\
.71 \\
.72 \\
\text { (i) } \\
.11 \\
4.80\end{array}$ & $\begin{array}{r}\text { Per cent } \\
0.09 \\
.09 \\
.12 \\
.18 \\
.05 \\
.02 \\
.49\end{array}$ & $\mid \begin{array}{r}\text { Per cent } \\
0.57 \\
.46 \\
.65 \\
.65 \\
.26 \\
1.03 \\
.12 \\
4.80\end{array}$ \\
\hline
\end{tabular}

I Sample dusted out of small container due to too rapid evacuation and therefore could not be weighed.

\section{MINOR GAS CONSTITUENTS}

Hydrogen "was not detected and carbon monoxide was indicated in only one sample (No. 8 in Table 4). It is not to be supposed from the evidence available that the carbon monoxide came from the feldspar itself or that the presence of an inclusion which might be the source of this gas has been established. Refinements of the method will be required in order to determine such gases as hydrogen sulfide, sulfur dioxide and nitrogen, should they be present.

\section{VOLUME RELATIONS OF GASES}

The volume of gases obtained from unit volume of the feldspars was calculated from the gravimetric data. The calculations involved the assumption that water vapor acted as a perfect gas at a temperature above $400^{\circ} \mathrm{C}$. and that the acid gases were composed entirely of carbon dioxide. The resulting values, necessarily approximate, are given in Table 5. The following are the extremes at $1,000^{\circ} \mathrm{C}$. for the 19 feldspars: One milliliter would yield from 16 to $140 \mathrm{ml}$ of water vapor and from 0 to $15 \mathrm{ml}$ of acid gases (as $\mathrm{CO}_{2}$ ) measured at $1,000^{\circ} \mathrm{C}$. 
TABLE 5.- Volume of gases evolved at different temperatures from feldspar No. 8 [Time of heating, one-half hour at each temperature; size of sample, $10 \mathrm{~g}$; volume of gas, calculated at maximum temperature of each range]

\begin{tabular}{|c|c|c|c|}
\hline Temperature range $\left({ }^{\circ} \mathrm{C}.\right)$ & $\mathrm{CO}_{2}$ & $\mathrm{CO}$ & $\begin{array}{l}\text { Water } \\
\text { vapor }\end{array}$ \\
\hline $\begin{array}{l}0-400 \\
400-500000 \\
600-8000000 \\
900-1,000 \\
1,000-1,100\end{array}$ & $\begin{array}{r}m l \\
0 \\
0 \\
1 \\
7 \\
14 \\
15 \\
\end{array}$ & $\begin{array}{r}m l \\
0 \\
<1 \\
<1 \\
3\end{array}$ & $\begin{array}{r}m l \\
43 \\
21 \\
24 \\
17 \\
35 \\
9 \\
6 \\
6 \\
6 \\
210\end{array}$ \\
\hline Total & 27 & 37 & 171 \\
\hline
\end{tabular}

1 Evolution of $\mathrm{CO}_{2}$ is complete at $900^{\circ} \mathrm{C}$.

2 Evolution of $\mathrm{CO}$ and $\mathrm{H}_{2} \mathrm{O}$ continues at least up to $1,200^{\circ} \mathrm{C}$.

\section{SUMMARY AND CONCLUSIONS}

The amounts of water vapor and acid gases were determined in 19 samples of ground commercial feldspars when heated in vacuo at a series of temperatures increasing in steps of $100^{\circ}$ from $400^{\circ}$ to $1,000^{\circ} \mathrm{C}$. The quantities of carbon monoxide and hydrogen were determined in some of these samples. A study also was made of the gases obtained on heating two of these feldspars from $400^{\circ}$ to $1,200^{\circ} \mathrm{C}$., in steps of $100^{\circ} \mathrm{C}$.

Water vapor began to come off as soon as the samples were heated above the drying temperature; the maximum amount was obtained between $800^{\circ}$ and $900^{\circ} \mathrm{C}$. The evolution of acid gases started at about $500^{\circ} \mathrm{C}$., the speed of evolution increasing rapidly between $600^{\circ}$ and $900^{\circ} \mathrm{C}$. No hydrogen and only small quantities of carbon monoxide were found.

At $1,000^{\circ} \mathrm{C}$. the gases were found to consist by weight of 32 to 96 per cent water vapor, of 0 to 59 per cent acid gases, and of 0 to 36 per cent unabsorbed gases. Volume calculations indicated that $1 \mathrm{ml}$ of feldspar would yield 16 to $40 \mathrm{ml}$ of water vapor and 0 to $15 \mathrm{ml}$ of acid gases (calculated as $\mathrm{CO}_{2}$ ) measured at $1,000^{\circ} \mathrm{C}$.

\section{ACKNOWLEDGMENTS}

The above investigation was carried out under a cooperative agreement between the Bureau of Standards and the Engineering Experiment Station of Ohio State University. Greatful acknowledgement is made to T. A. Klinefelter, L. Jordan, and H. C. Vacher, and also to Prof. A. S. Watts, who represented the Engineering Experiment Station, for advice and assistance.

WASHington, June 8, 1931. 